\title{
ANALISIS ALAT BUKTI YANG SAMA DALAM PERKARA PIDANA YANG BERBEDA (STUDI KASUS SETYA NOVANTO DALAM PUTUSAN PRAPERADILAN PENGADILAN NEGERI JAKARTA SELATAN NOMOR: 97/PID.PRAP/2017/PN.JKT.SEL)
}

\author{
Alnan Marchelita Pradewi \\ (Mahasiswa Program S1 Fakultas Hukum Universitas Tarumanagara)
}

\section{Firman Wijaya}

(Corresponding Author)

(Dosen Hukum Pidana Fakultas Hukum Universitas Tarumanagara, Meraih Sarjana Hukum dari Fakultas Hukum Universitas Tarumanagara, Magister Hukum dari Fakultas Hukum Universitas 17 Agustus 1945 Jakarta, Doktor Hukum dari Fakultas Hukum Universitas Krinadwipayana)

\begin{abstract}
Evidence is the important instrument to decide criminal cases and Its began from investigation, prosecution, until court decisions. Evidence is arrange in article 184 and explanation of KUHAP. Police investigating to determine someone be a suspect or unknown through investigation about entanglement according to evidence any goods and the evidence available. In fact many law enforcement officials such as police used power revenue and their authority to quickly resolve the cases with no accordance to the procedure. Therefore to minimize those things law enforcement need supervision as pretrial. Pretrial have authority to judge about legal or failure arrest, detention termination investigation or termination prosecution; compensation and or rehabilitation for criminal cases stopped at the investigation or prosecution. Related to the verdict of South Jakarta District Court number 97/Pid.prap/2017/Pn.Jkt.Sel, judge Cepi Iskandar said that the same evidence cannot be used as evidence in other criminal cases brought many different polemics. Generally judge decide on criminal cases based to article 183 KUHAP and in fact many criminal cases was using the same evidence especially to cases with more than one defendant or participation cases. Judge Cepi Iskandar decision have given uncertainty law in the public, so it needs analysis and further discussion about the evidence and the consideration on that judicial decisions.
\end{abstract}

Keywords: Evidence, Pretrial 


\section{PENDAHULUAN}

\section{A. Latar Belakang}

Indonesia merupakan negara hukum sebagaimana diatur dalam Pasal 1 Ayat (3) Undang-Undang Dasar Negara Republik Indonesia Tahun 1945 sehingga keberadaan hukum menjadi unsur penting kehidupan bermasyarakat. Keberadaan hukum menurut L.J. Apeldoorn dilihat dari tujuannya adalah untuk mengatur tata tertib dalam masyarakat secara damai dan adil. ${ }^{1}$ Padangan ini memberi arti bahwa adanya hukum memberi pelayanan bagi masyarakat sehingga tercipta suatu ketertiban, keamanan, keadilan dan kesejahteraan. Makna dalam menjalankan kehidupan bernegara tersebut salah satunya dengan penanganan dalam menyelesaikan masalah sosial yang disebut tindak pidana. Van Hamel merumuskan delik (strafbaarfeit) itu sebagai berikut: "Kelakuan manusia yang dirumuskan dalam Undang-Undang, melawan hukum, yang patut dipidana dan dilakukan dengan kesalahan." 2) Dalam menangulangi kejahatan, Indonesia menggunakan dasar pendekatan sistem yakni sistem peradilan pidana (criminal justice system) dengan dasar open system yaitu suatu sistem yang di dalam gerakan mencapai tujuan baik tujuan jangka pendek (resosialisasi), jangka menegah (pencegahan kejahatan) maupun jangka panjang (kesejahteraan sosial) dengan pengaruh dari lingkungan masyarakat dan bidang-bidang dalam kehidupan manusia, sistem peradilan pidana bergerak dan mengalami interface. Komponen-komponen yang bekerjasama dalam sistem peradilan pidana ini, berdasarkan KUHAP adalah Kepolisian, Kejaksaan, Pengadilan, dan Lembaga Pemasyarakatan. Keempat komponen ini diharapkan bekerjasama membentuk suatu apa yang dikenal dengan nama integrated criminal justice system (sistem peradilan pidana terpadu).

Berjalannya keempat komponen tersebut dalam peradilan pidana bertumpu pada "mencari kebenaran". Kebenaran yang dicari merupakan

${ }^{1)}$ R. Soeroso, Pengantar Ilmu Hukum. Cet. 11, (Jakarta: Sinar Grafika, 2009), hal. 57 hal. 96 .

2) Andi Hamzah, Asas-Asas Hukum Pidana. Cet. Ke-4, (Jakarta: PT Rienka Cipta, 2010), 
kebenaran materiil yang muncul dari alat bukti. Alat bukti adalah segala sesuatu yang ada hubungannya dengan suatu perbuatan, dimana dengan alat-alat bukti tersebut, dapat dipergunakan sebagai bahan pembuktian guna menimbulkan keyakinan hakim atas kebenaran adanya suatu tindak pidana yang telah dilakukan terdakwa. ${ }^{3)}$ Dalam Pasal 184 Ayat (1) Kitab Undang-Undang Hukum Acara Pidana ('KUHAP") disebutkan bahwa alat bukti yang sah adalah: ${ }^{4)}$ a. Keterangan saksi; b. Keterangan ahli; c. Surat; d. Petunjuk; e. Keterangan Terdakwa. Dimulai dari tahap penyelidikan ${ }^{5)}$ yakni untuk menentukan apakah suatu perkara merupakan perkara pidana yang kemudian dilanjutkan dengan tahap penyidikan ${ }^{6)}$ untuk menetapkan status tersangka seseorang. Setelah tahap penyidikan maka dilanjutkan ke tahap penuntutan lalu ketahap pengadilan.

Penentuan status tersangka seseorang pada tahap penyidikan merupakan tahapan yang penting serta harus dilakukan secara hati-hati. Hal ini sudah diatur dalam Pasal 1 angka 10 KUHAP yang berbunyi "tersangka adalah seorang yang karena perbuatannya atau keadaannya, berdasarkan bukti permulaan patut diduga sebagai pelaku tindak pidana" selain itu, dalam Pasal 1 angka 20 menyebutkan bahwa "penangkapan adalah suatu tindakan penyidik berupa pengekangan sementara waktu kebebasan tersangka atau terdakwa apabila terdapat cukup bukti guna kepentingan pernyidikan atau penuntutan dan atau peradilan dalam hal

\footnotetext{
${ }^{3)}$ Hari Sasangka dan Lily Rosita, Hukum Pembuktian Dalam Perkara Pidana, (Bandung: Mandar Maju, 2003), hal. 11.

4) Eddy Hiariej O.S, Teori \& Hukum Pembuktian, (Jakarta: Erlangga, 2012), hal. 12.

${ }^{5)}$ Indonesia, Kitab Undang-Undang Hukum Acara Pidana, No. 8 Tahun 1981, LN No. 9 Tahun 1951, TLN No. 81, Ps. 1 butir 4. Berbunyi : "Penyelidikan adalah serangkaian tindakan penyelidik untuk mencari dan menemukan suatu peristiwa yang diduga sebagai tindak pidana guna menentukan dapat atau tidaknya dilakukan penyidikan menurut cara yang diatur dalam undangundang ini”. Ranah penyelidikan dilakukan oleh Penyelidik yang merupakan pejabat polisi negara republik indonesia denagn kewajiban dan hak sebagaimana disebutkan dalam Pasal 5 KUHAP.

6) Ibid, Pasal 1 angka 2. Menyebutkan bahwa "Penyidikan adalah serangkaian tindakan penyidik dalam hal dan menurut cara yang diatur dalam undang-undang ini untuk mencari serta mengumpulkan bukti yang dengan bukti itu membuat terang tentang tindak pidana yang terjadi dan guna menemukan tersangkanya. Adapun komponena atau alat negara yang berwenang melakukan penyidikan disebut dengan "penyidik" pada pasal 1 angka 1 KUHAP menjelaskan "penyidik adalah pejabat polisi Negara Republik Indonesia atau Pejabat Pegawai Negeri Sipil tertentu yang diberi wewenang khusus oleh undang-undang untuk melakukan penyidikan". Kewajiban, wewenang serta tugas dari penyidik diatur dalam Pasal 6 sampai 9 KUHAP.
} 
serta menurut cara yang diatur dalam undang-undang ini”. Adanya frasa "bukti permulaan" ataupun "cukup bukti" dalam kedua pasal tersebut menjelaskan bahwa alat bukti menjadi komponen yang penting dalam menetapkan seseorang sebagai tersangka. Ketika frasa "bukti permulaan" atau "cukup bukti" tidak terpenuhi maka tidak dapat ditetapkannya seseorang sebagai tersangka sehingga harus dilakukan penghentian penyidikan. Demi menjaga hak asasi dari tersangka tersebut maka dapat diajukan gugatan praperadilan. Praperadilan ${ }^{7}$ ) merupakan bagian dari pengadilan negeri yang melakukan fungsi pengawasan terutama dalam hal dilakukan upaya paksa terhadap tersangka oleh penyidik atau penuntut umum. Tujuan utama dari Praperadilan yakni untuk pengawasan dalam suatu proses pidana untuk menjaga penyalagunaan wewenang ataupun kekuasaan oleh para aparat penegak hukum.

Pada Senin, 17 Juli 2017 lalu, Komisi Pemberantasan Korupsi (selanjutnya disebut "KPK") menetapkan Mantan Ketua DPR RI, Setya Novanto sebagai tersangka yang diduga terlibat korupsi proyek pengadaan Kartu Tanda Penduduk berbasis elektronik (e-KTP). Setya Novanto diduga telah menguntungkan diri sendiri atau orang lain atau korporasi dengan menyalahgunakan kewenangan dan jabatan. Korupsi E-KTP tersebut mengakibatkan kerugian negara Rp2,3 triliun dari nilai proyek Rp 5,9 triliun. Setya Novanto disangka melanggar Pasal 3 atau Pasal 2 Ayat (1) Undang-Undang Nomor 31 Tahun 1999 sebagaimana diubah dalam Undang-Undang Nomor 20 Tahun 2001 tentang Pemberantasan Tindak Pidana Korupsi jo Pasal 55 Ayat (1) ke-1 KUHP. ${ }^{8)}$

\footnotetext{
${ }^{7)}$ Ibid, Pasal 1 angka 10 menyebutkan "Praperadilan adalah wewenang pengadilan negeri untuk memeriksa dan memutus menurut cara yang diatur dalam undang-undang ini tentang : a. Sah atau tidaknya Sah atau tidaknya suatu penangkapan dan/atau penahanan atas permintaan tersangka atau keluarganya atau pihak lain atas kuasa tersangka; b. Sah atau tidaknya penghentian penyidikan atau penghentian penuntutan atas permintaan tersangka/ penyidik/ penuntut umum demi tegaknya hukum dan keadilan; c.Permintaan ganti kerugian atau rehabilitasi oleh tersangka atau keluarganya atau pihak lain atas kuasanya, yang perkaranya tidak diajukan ke pengadilan.

8 ) http://nasional.kompas.com/read/2017/07/17/19034751/kpk-tetapkan-setyanovanto-tersangka-kasus-e-ktp, diakses pada Sabtu, 3 Februari 2018, Pukul 15.10 WIB.
} 
Pada Jumat, 29 September 2017, Hakim tunggal, Cepi Iskandar, mengabulkan gugatan praperadilan Setya Novanto dengan menyatakan penetapan Ketua DPR itu sebagai tersangka tidak sesuai dengan prosedur. Hakim Cepi mempertimbangkan bahwa penetapan tersangka oleh KPK tidak berdasarkan prosedur dan tata cara Undang-Undang Nomor 30 Tahun 2002 tentang Komisi Pemberantasan Tindak Pidana Korupsi, KUHAP, dan SOP KPK. Namun KPK mempertimbangkan untuk mengeluarkan lagi surat perintah penyidikan (sprindik) untuk Setya Novanto. ${ }^{9)}$

Peneliti Bidang Hukum Indonesia Corruption Watch (ICW), Lalola Easter, mengaku tak heran dengan putusan hakim pada sidang praperadilan Ketua DPR RI Setya Novanto yang mengabulkan gugatan Setya Novanto. salah satu dalil hakim yang paling kontroversial dalam putusan praperadilan itu adalah bahwa alat bukti untuk tersangka sebelumnya tidak bisa dipakai lagi untuk menetapkan tersangka lain. Menurut Lalola, itu artinya mendelegitimasi putusan Majelis Hakim yang memutus perkara E-KTP dengan terdakwa Irman dan Sugiharto, yang notabene sudah berkekuatan hukum tetap. ${ }^{10)}$

Berdasarkan uraian diatas, maka peneliti telah melakukan penelitian dengan judul: "Analisis Alat Bukti yang Sama dalam Perkara Pidana yang Berbeda (Studi Kasus Setya Novanto dalam Putusan Praperadilan Pengadilan Negeri Jakarta Selatan Nomor: 97/Pid.Prap/2017/PN.Jkt.Sel)"

\section{B. Permasalahan}

Berdasarkan latar belakang sebagaimana diuraikan di atas, permasalahan yang dikaji dalam artikel ini adalah:

\footnotetext{
9) https://nasional.tempo.co/read/1021611/praperadilan-setya-novanto-ma-tak-hilangkanperbuatan-pidana, Pada Sabtu, 3 Februari, 2018, pukul 15:20 WIB.

10 ) http://nasional.kompas.com/read/2017/09/30/06581381/icw-kemukakan-6kejanggalan-putusan-hakim-praperadilan-setya-novanto, diakses Pada Sabtu, 3 Februari, 2018, pukul 15:30 WIB.
} 
1. Bagaimana pengaturan mengenai alat bukti dan barang bukti dalam peraturan pidana di Indonesia?

2. Bagaimana pertimbangan Hakim dalam putusan praperadilan Pengadilan Negeri Jakarta Selatan No. 97/Pid.Prap/2017/Pn.Jkt.Sel mengenai alat bukti yang sama dalam perkara pidana yang berbeda?

\section{Metode Penelitian}

Penelitian dilakukan guna menemukan sumber-sumber diperlukan untuk memprediksi apa yang akan dilakukan sehingga dapat diketahui apa tindakan-tindakan yang dapat diambil. ${ }^{11}$ ) Sehingga dalam metode penelitian yang merupakan proses untuk menemukan aturan hukum, prinsip hukum maupun doktrin hukum untuk menyelesaikan isu hukum yang ada.

\section{Tipe Penelitian}

Tipe penelitian yang akan digunakan oleh penulis dalam penelitian ini adalah penelitian yuridis normatif. Penulis menggunakan penelitian ini karena Penulis mengkaji kaidah-kaidah atau norma-norma dalam hukum positif ${ }^{12}$ terkait penggunaan alat bukti yang sama dalam perkara yang berbeda disesuaikan dengan keadaan yang terjadi saat ini, dikenal dengan istilah das sollen das sein. ${ }^{13}$ Adapun pendekatratan penelitian yang digunakan berupa pendekatan peraturan perundang-undangan (statue approach) dan pendekatan kasus (case approach) ${ }^{14)}$

11) Peter Mahmud Marzuki, Penelitian Hukum, (Edisi revisi), (Jakarta: Kencana Prenada Media Group, 2009), hal. 57.

${ }^{12)}$ Johny Ibrahim, Teori dan Metodologi Penelitian Hukum Normatif, (Malang, Publishing, 2006), hal. 295.

13 ) Norma-norma terdiri dari beberapa macam seperti : norma moral, norma kesusilaan, norma etika, norma hukum, norma agama, dan lain-lain. Namun, dari beberapa norma tersebut terdapat sebuah norma yang dianggap paling kuat yakni norma hukum. Norma hukum adalah aturan sosial yang dibuat oleh lembaga-lembaga tertentu, seperti pemerintah, sehingga denagn tgas dapat melarang serta memaksa orang untuk dapat berperilaku sesuai dengan keinginan pembuat peraturan itu. Pelanggaran terhadap norma akan diberikan sanksi yang dapat berupa sanksi denda hingga hukuman fisik berupa dipenjara ataupun hukuman mati. Sebagai mana Pasal 10 KUHP menetapkan bahwa sanksi pidana terdiri atas pidana pokok yakni pidana mati, pidana penjara, pidana kurungan, pidana denda, dan pidana tutupan . selain itu, ada juga pidana tambahan berupa pencabutan hak-hak tertentu, perampasan barang-barang tertentu, dan pengumuman putusan hakim. Norma hukum memilki kehendak yakni Das Sollen.

${ }^{14)} \mathrm{Ibid}$, hal. 133. 


\section{Jenis Bahan Penelitian}

Jenis bahan penelitian yang akan dipergunakan oleh Penulis dalam penelitian ini antara lain sebagai berikut:

a. Bahan Hukum

1) Bahan hukum primer, yakni, badan hukum yang bersifat autoritatif, artinya mempunyai otoritas. ${ }^{15)}$ Lebih lanjut bahan hukum primer dalam penelitian ini adalah UUD 1945, KUHP, KUHAP, UU Kekuasaan Kehakiman dan UU Tipikor.

2) Bahan hukum sekunder, yakni, semua publikasi tentang hukum yang merupakan dokumen resmi. ${ }^{16)}$ Publikasi yang dimaksud adalah publikasi mengenai hukum meliputi pandangan para ahli (doktrin), teks hukum, kamus-kamus hukum, jurnal-jurnal hukum, dan komentar-komentar atau putusan-putusan pengadilan serta buku-buku teks dan jurnal-jurnal hukum yang bersangkutan dengan pokok pembahasan;

\section{b. Bahan Nonhukum}

Bahan nonhukum dapat berupa buku-buku mengenai ilmu politik, ekonomi, sosiologi, filsafat, kebudayaan, ataupun laporanlaporan penelitian non-hukum, dan jurnal-jurnal nonhukum sepanjang mempunyai relevansi dengan topik penelitian yang kemudian sebatas sebagai pelengkap ${ }^{17)}$ Selain daripada itu, bahan nonhukum juga dapat berupa wawancara, dialog, kesaksian ahli hukum di pengadilan, seminar, ceramah, dan kuliah. ${ }^{18)}$

\section{Spesifikasi Penelitian}

Spesifikasi penelitian yang digunakan dalam penelitian ini bersifat deskriptif analitis, yaitu "untuk menemukan, menggambarkan secara menyeluruh, dan mengkaji norma-norma hukum positif". ${ }^{19)}$ Penelitian

${ }^{15)}$ Ibid, hal. 181.

${ }^{16)}$ H. Zainudin Ali, Metode Penelitian Hukum, (Jakarta: Sinar Grafika, 2009), hal. 47.

17) Ibid, hal. 183-184.

${ }^{18)}$ Ibid, hal. 206.

${ }^{19)}$ I Made Pasek Diantha, Metodologi Penelitian Hukum Normatif dalam Justifikasi Teori Hukum, Cet ke-1, (Jakarta: Prenada Media Group,2016), hal. 156. 
deskriptif analitis difokuskan pada norma hukum primer seperti peraturan perundang-undangan dan putusan pengadilan yang berkaitan dengan alat bukti khususnya berkaitan dengan penggunaan alat bukti yang sama dalam perkara pidana yang berbeda.

\section{Teknik Analisis Data}

Analisis data dalam penelitian ini bersifat induktif, yaitu "pengembangan konsep yang didasarkan atas data yang ada, mengikuti desain penelitian yang fleksibel sesuai dengan konteksnya. Desain tersebut tidak kaku sehingga memberi peluang kepada peneliti untuk menyesuaikan diri dengan konteks yang ada di lapangan",20)

\section{PEMBAHASAN}

\section{A. Pengaturan Mengenai Alat Bukti dan Barang Bukti dalam Peraturan Pidana di Indonesia}

Alat bukti dan barang bukti merupakan komponen yang sangat penting dalam menyelesaikan suatu perkara di persidangan. Alat bukti adalah segala sesuatu yang ada hubungannya dengan suatu perbuatan, dimana dengan alat-alat bukti tersebut, dapat dipergunakan sebagai bahan pembuktian guna menimbulkan keyakinan hakim atas kebenaran adanya suatu tindak pidana yang telah dilakukan terdakwa. ${ }^{21}$ Selain itu, Martiman Prodjohamidjojo menyatakan bahwa barang bukti atau corpus delicti adalah barang bukti kejahatan. ${ }^{22}$ Ansori Hasibuan berpendapat barang bukti ialah barang yang digunakan oleh terdakwa utnuk melakukan suatu delik atau sebagai hasil suatu delik, disita oleh penyidik untuk digunakan sebagai barang bukti pengadilan. ${ }^{23}$

${ }^{20)}$ Beni Ahmad Soebani, Metode Penelitian Hukum, Cet ke-1, (Bandung: Pustaka Setia, 2009), hal. 103.

${ }^{21)}$ Alfitra, Hukum Pembuktian dalam Beracara Pidana, Perdata dan Korupsi di Indonesia, (Jakarta: Raih Asa Sukses, 2011), hal. 23.

22) Martiman Prodjohamidjojo, Sistem Pembuktian dan Alat-alat Bukti, (Jakarta: Ghalia Indonesia, 1983), hal. 19.

23) Ansori Hasibuan, Syarifuddin Petenasse, Ruben Ahmad, Hukum Acara Pidana, (Bandung: Angkasa, 1990), hal. 182. 
Pengaturan mengenai alat bukti dan barang bukti dalam peraturan pidana di Indonesia diatur dalam beberapa peraturan. Secara umum alat bukti sudah diatur sejak dahulu kala dan tertuang dalam Herzien Inlandsch Reglement (H.I.R) atau yang dikenal sebagai Reglemen Indonesia yang Diperbaharui (R.I.B). Pasal 295 H.I.R mengatur mengenai alat bukti yang berisi bahwa sebagai upaya bukti menurut undang-undang hanya diakui .24)

1. Kesaksian-kesaksian.

Kesaksian yang dimaksud yaitu keterangan lisan seorang, dimuka sidang pengadilan, dengan disumpah lebih dahulu, tentang peristiwa tertentu yang didengar, dilihat dan dialami sendiri. Kesaksian yang tidak dilihat sendiri, akan tetapi menganai hal-hal yang dikatan oleh oramg lain bukanlah merupakan kesaksian yang syah. Kesaksian seperti ini biasa disebut saksi "de auditu".

2. Surat-surat.

Surat-surat sebagai bukti ditentukan dalam beberapa pasal yakni dalam Pasal 304 H.I.R. menentukan bahwa peraturan tentang kekuatan bukti surat-surat umum dan surat-surat khusus dalam perkara perdata harus diperhatikan pula terhadap bukti dalam perkara pidana.

3. Pengakuan.

Pengakuan yaitu ketereangan terdakwa, bahwa ia mengaku telah melakukan suatu peristiwa pidana yang dituduhkan kepadanya. Supaya pengakuan itu merupakan alat bukti yang cukup sebagaimana Pasal 307 H.I.R maka pengakuan harus memenuhi syarat-syarat berupa : diberikan atas kehendak sendiri atau bebas dari paksaan, diberikan di muka sidang pengadilan, dan disertai dengan pemberitahuna yang tentu dan seksama, tentang sesuatu yang diketahui, baik dari keterangan orang yang menderita peristiwa

24 ) Herziene Inlandsch Reglement, Reglemen Indonesia yang Diperbaharui, related:www.hukumonline.com/pusatdata/downloadfile/fl53195/parent/27228 hir. Pasal 295 H.I.R 
pidana, maupun dari alat-alat bukti lainnya yang cocok dengan pengakuan itu.

4. Isyarat-isyarat.

Isyarat adalah terjemahan dari bahasa Belanda "aanwijzingen" dengan terjemahan berupa "tanda-tanda" atau "penunjukkan-penunjukkan". Dimana dalam Pasal 310 H.I.R yang dimaksud penunjukan yaitu perbuatan-perbuatan, kejadian-kejadian atau keadaan-keadaan yang adanya dan persetujuannya, baik yang satu denga yang lain, maupun dengan kejahatan itu sendiri dengan nyata menujukkan, bahwa ada suatu kejadian telah dilakukan dan siapakah pembuatnya.

Terkait Barang bukti juga sudah diatur dalam Pasal 42 H.I.R yang perlu dibeslag yakni : ${ }^{25)}$

1. Barang-barang yang menjadi sasaran tindak pidana, seperti misalnya barang-barang yang dicuri, digelapkan, ditipu dan lain sebagainya.

2. Barang-barang yang terjadi sebagai hasil dari tindak pidana, seperti misalnya uang logam atau uang kertas palsu yang telah dibuat oleh terdakwa. Barang-barang tersebut pada nomor 1 dan 2 ini adalah barnag-barang yang disebut "corpora delicti".

3. Barang-barang yang dipergunakan untuk melakukan tindak pidana seperti misalnya golok atau pistol yang dipakai untuk menganiaya atau membunuh orang, golo atau alat lain yang dipergunakan membongkar rumah untuk mencur, racun untuk membunuh, alat-alat untuk membuat uang palsu dan lain sebagainya, yang biasa disebut "instrumenta delicti"

4. Barang-barang lain yang pada umumnya dapat dipergunakan untuk memberatkan atau meringankan kesalahan terdakwa, seperti misalnya pakaian kena darah yang dipakai tersangka membunuh orang, kaca jendela yang ada bekas telapak jari dari orang yang mencuri dan lain sebagainya, yang termasuk pula dalam sebutan "corpora delicti".

${ }^{25)}$ Ibid. Pasal 42 ayat (2) H.I.R 
Secara umum pengaturan mengenai alat bukti yang digunakan pada saat ini adalah Pasal 164 H.I.R, Pasal 284 Rbg, dan Pasal 1886 Kitab Undang-Undang Hukum Acara Perdata (burgerlijk weboek) yakni alat bukti terdiri dari 5 (lima) jenis yakni alat bukti tertulis, alat bukti saksi, alat bukti persangkaan, alat bukti pengakuan, alat bukti sumpah. Sedangkan dalam menangani perkara pidana maka alat bukti yang digunakan berdasarkan Pasal 184 KUHAP adalah sebagai berikut : ${ }^{26)}$

1. Keterangan Saksi

Keterangan saksi adalah keterangan yang didengar, dilihat, dan dialami sendriri dengan didukung dasar atas pengetahuannya (Pasal 1 angka 27 KUHAP)

2. Keterangan Ahli

Keterangan ahli adalah keterangan yang diberikan oleh seorang yang memiliki keahlian khusus tentang hal yang diperlukan untuk membuat terang suatu perkara pidana guna kepentingan pemeriksaan.

3. Surat

Surat adalah pembawa tanda tangan bacaan yang berarti, yang menerjemahkan suatu isi pikiran. Ketentuan mengenai hal-hal yang dapat disebut sebagai surat tertuang dalam Pasal 187 KUHAP.

4. Petunjuk

Pasal 188 menyatakan bahwa petunjuk adalah perbuatan, kejadian atau keadaan, yang karena persesuaiannya, baik antara yang satu dengan yang lain, maupun dengan tindak pidana itu sendiri, menandakan bahwa telah terjadi suatu tindak pidana dan siapa pelakunya. Dalam Pasal 188 ayat (2) petunjuk hanya dapat diperoleh dari keterangan saksi, surat, dan keterangan terdakwa.

5. Keterangan Terdakwa

${ }^{26)}$ Indonesia, Kitab Undang-Undang Hukum Acara Pidana, UU Nomor 8 Tahun 1981, LN Nomor 8 Tahun 1981, TLN No. 3258, Pasal 1 KUHAP dan Pasal 184 KUHAP. 
Pasal 189 KUHAP menyatakan bahwa keterangan terdakwa ialah apa yang terdakwa nyatakan di sidang tentang perbuatan yang ia lakukan atau yang diketahui sendiri atau alami sendiri; yang diberukan di luar sidang dapat digunakan untuk membantu menemukan bukti di sidang, asalkan keterangan itu diukung oleh sautu alat bukti yang sah sepanjang mengenai hal yang didakwakan kepadanya; hanya dapat digunakan terhadap dirinya sendiri; keterangan terdakwa saja tidak cukup untuk membuktikan bahwa ia bersalah melakukan perbuatan yang didakwakan kepadanya, melainkan harus disertai dengan alat bukti yang lain.

Pengaturan mengenai Barang bukti pada saat ini tertuang dalam Pasal 39 ayat (1) KUHAP dimasukan dalam penjelasan terkait penyitaan ${ }^{27)}$ yakni

1. Benda atau tagihan tersangka atau terdakwa yang seluruh atau sebagian diduga diperoleh dan tindak pidana atau sebagai hasil tindak pidana;

2. Benda yang telah dipergunakan secara langsung untuk melakukan tindak pidana atau untuk mempersiapkannya;

3. Benda yang dipergunakan untuk menghalang-halangi penyidikan tindak pidana;

4. Benda yang khusus dibuat atau diperuntukkan melakukan tindak pidana;

5. Benda lain yang mempunyai hubungan langsung dengan tindak pidana yang dilakukan.

Ubi Societas Ibi Ius $^{28)}$ dimaknai sebagai dimana ada masyarakat disitu ada hukum. Hal ini sejalan dengan perkembangan masyarakat setiap

${ }^{27)}$ Ratna Nurul Afiah, Barang Bukti Dalam Proses Pidana, (Jakarta: Sinar Grafika, 1989), hal. 
harinya sehingga hukumpun harus memperbaharui diri untuk mengisi kekosongan dan dapat sejalan dengan keberadaan masyarakat. Melihat hal tersebut para penegak hukum tidak hanya berpegang pada Kitab UndangUndang Hukum Acara Pidana namun ada juga beberapa perluasan alat bukti yang diatur dalam peraturan-peraturan lain baik dalam undangundang ataupun peraturan kepolisian republik Indonesia. Selain itu, Mahkamah Konstitusi juga melakukan perluasan dalam alat bukti. Berdasarkan penjelasan Pasal 184 KUHAP yang hanya mengatur 5 (lima) jenis alat bukti yang sah, sehingga alat bukti yang digunakan diluar ketentuan Pasal 184 KUHAP akan dianggap bukan sebagai alat bukti dan tidak dibenarkan utnuk membuktikan kesalahan pelaku tindak pidana. Hal tersebut tidak memberikan perlindungan dan kepastian hukum bagi masyarakat sehingga memaknai sistem peradilan pidana yang dianut di Indonesia dan dilihat dari segi fungsional, dimana Barda Nawawi Arief menyatakan bahwa sistem peradilan pidana yang fungsional berarti harus adanya keselarasan antara peraturan yang dibuat serta pelaksanaan peraturan oleh aparat penegak hukum.

Selain Undang-Undang ada pula Peraturan Kepala Kepolisian Republik Indonesia yang menjadi pedoman bagi aparat penegak hukum yakni penyidik dalam melakukan penyelidikan dan penyidikan bahwa mengenai pencarian alat bukti dan barang bukti diatur ketentuan dalam pengertian yang tertuang dalam Pasal 1 angka 20 sampai Pasal 1 angka 23 serta Pasal 2 Peraturan Kepala Kepolisian Negara Republik Indonesia Nomro 14 Tahun 2012 tentang Manajemen Penyidikan Tindak Pidana. Putusan Mahkamah Konstitusi Nomor. 20/PUU-XIV/2016 ${ }^{29)}$ mengenai

${ }^{28)}$ Ubi societas ibi ius adalah ungkapan yang dikemukakan oleh Marcus Tulius Cicero yang artinya "dimana ada masyarakat di situ ada hukum." Ungkapan klasik tersebut memberikan gambaran bahwa kapan hukum pertama kali tercipta, pertanyaan tersebut mengandung pengertian yaitu bahwa hukum tercipta pada saat manusia tercipta juga, karena pada saat ada manusia dan pergaulannya pada saat itulah hukum sudah ada. Jawaban adalah sejak manusia pertama kali diciptakan oleh Sang Pencipta. Dikutip dari buku Peter Mahmud Marzuki, Pengantar Ilmu Hukum Edisi Revisi, (Jakarta: Kencana Prenanda Media Group, 2013), hal. 41.

29) Putusan Mahkamah Konstitusi Nomor 20/PUU-XIV/2016 yang diajukan oleh Drs. Setya Novanto dengan memberikan kuasa berdasarkan surat kuasa khusus kepada Muhammad 
bukti elektronik (digital) sebagai alat bukti dan Putusan Mahkamah Agung Nomor. 42/PUU-XV/2017 ${ }^{30)}$ mengenai kedudukan dan syarat penggunaan alat bukti yang sama terkait implikasinya pada perkara pidana yang berbeda dan dapat digunakan untuk mengeluarkan Surat Perintah dimulainya Penyidikan (SPRINDIK).

\section{B. Pertimbangan hakim dalam Putusan Praperadilan Pengadilan Negeri Jakarta Selatan No. 97/Pid.Prap/2017/Pn.Jkt.Sel Mengenai Alat Bukti yang Sama dalam Perkara Pidana yang Berbeda.}

Pasal 80 KUHAP menyatakan bahwa Praperadilan merupakan salah satu kewenangan pengadilan dan juga penerapan upaya paksa oleh Polisi dan Jaksa meliputi: sah atau tidaknya penangkapan, penahanan, penghentian penyidikan atau penghentian penuntutan yang dapat diajukan oleh penyidik atau penuntut umum atas pihak ketiga yang berkepentingan. Namun, saat ini objek praperadilan sudah diperluas berdasarkan putusan Mahkamah Konstitusi Nomor 21/PUU-XII/2014 yakni mengenai sah atau tidaknya penetapan tersangka, penggeledahan dan penyitaan. Menurut Hakim Achmad Guntur melalui wawancara menyatakan bahwa tatacara dalam pelaksanaan Praperadilan sebenarnya mengikuti tata cara hukum acara perdata. Selain itu, M. Yahya Harahap juga menjelaskan bahwa praperadilan dilakukan dengan cara cepat mulai dari penunjukan hakim, penetapan hari sidang, pemanggilan para pihak dan pemeriksaan sidang guna dapat menjatuhkan putusan selambat-lambatnya dalam waktu tujuh hari. Bertitik tolak dari prinsip acara pemeriksaan cepat, bentuk putusan praperadilan pun sudah selayaknya menyesuaikan diri dengan sifat proses tadi. Oleh karena itu, bentuk putusan praperadilan cukup sederhana tanpa mengurangi isi pertimbangan yang jelas berdasar hukum dan undang-undang. Namun,

Ainul Syamsu, S.H.,M.H., Syaefullah Hakid, S.H., Hafisullah Amin Nasution, S.H., dan Teuku Mahdar Ardian,S.HI, Advokat di Kantor Hukum Syamsu Hamid \& Partners.

30) Putusan Mahkamah Konstitusi Nomor 42/PUU-XV/2017 mengenai alat bukti yang diajukan oleh Anthony Chandra Kartawiria dengan pemberian kuasa kepada Ricky Kurnia Margono, S.H., M.H., David Surya, S.H.,M.H., H. Adidharma Wicaksono, S.H., LL.M., Hendro Sismoyo, S.H., M.H. yaitu advokat dan konsultan hukum di Law Firm Margono-Surya \& Partners 
jangan sampai sifat kesederhanaan bentuk putusan menghilangkan penyusunan pertimbangan yang jelas dan memadai. Sifat kesederhanaan bentuk putusan praperadilan tidak boleh mengurangi dasar alasan pertimbangan yang utuh dan menyeluruh. ${ }^{31)}$

Pada 29 September 2017 Hakim Cepi Iskandar yang merupakan hakim tunggal dalam memeriksa dan memutus gugatan praperadilan di Pengadilan Negeri Jakarta Selatan dengan Nomor putusan 97/Pid.Prap/2017/Pn.Jkt.Sel terkait penetapan status tersangka Setya Novanto cukup kontroversial. Dalam putusannya, Hakim Cepi Iskandar mengabulkan gugatan Setya Novanto dan memberhentikan penyidikan dengan amar sebagai berikut :

\section{E N G A D I L I:}

\section{DALAM EKSEPSI:}

-Menolak eksepsi Termohon (KPK) untuk seluruhnya :

\section{DALAM POKOK PERKAR:}

1. Mengabulkan Permohonan Praperadilan PEMOHON (Setya Novanto) untuk sebagian;

2. Menyatakan penetapan Tersangka terhadap SETYA NOVANTO (Pemohon) yang dikeluarkan oleh Termohon berdasarkan Surat No. 310/23/07/2017 tanggal 18 Juli 2017, dinyatakan tidak sah;

3. Memerintahkan kepada Termohon untuk menghentikan penyidikan terhadap SETYA NOVANTO (Pemohon) berdasarkan Surat Perintah Penyidikan No. Sprin.Dik-56/01/07/2017 tanggal 17 Juli 2017;

4. Menghukum TERMOHON untuk membayar biaya perkara kepada negara sebesar nihil.

Dalam gugatannya Setya Novanto mengajukan 7 (tujuh) poin yakni: ${ }^{32)}$ poin pertama adalah hakim diminta mengabulkan permohonan praperadilan

${ }^{31)}$ M. Yahya Harahap, Pembahasan Permasalahan dan Penerapan KUHAP, Pemeriksaan Sidang Pengadilan, Banding, Kasasi dan Peninjauan Kembali. Edisi Kedua. (Jakarta: Sinar Grafika, 2006), hal. 17-18.

32 ) https://www.indopos.co.id/index.php/read/2017/09/20/110884/simak-ini-7-poinpermohonan-praperadilan-setya-novanto, diakses pada Minggu, 27 Mei 2018, Pukul 20:16 WIB. 
Novanto sebagai pemohon untuk seluruhnya dan meminta hakim menyatakan penetapan tersangka oleh KPK (Komisi Pemberantasan Korupsi) berdasarkan Nomor 310/23/07/2017 tertanggal 18 Juli 2017, tidak sah. Poin kedua, menyatakan batal atau batal demi hukum dan tidak sah penetapan tersangka kepada Setya Novanto atau pemohon yang dikeluarkan termohon (KPK). Poin ketiga, kuasa hukum Novanto meminta pengadilan untuk menghentikan penyidikan atas Surat Perintah Penyirikan No. Sprin.Dik- 56/01/07/2017 tertanggal 17 Juli 2017. Poin Keempat, Novanto meminta Hakim memerintahkan KPK untuk mencabut penetapan pencegahan dirinya berpergian ke luar negeri. Poin kelima, hakim diminta memerintahkan KPK untuk mengeluarkan Novanto dari tahanan apabila ditahan dalam perkara tersebut. Poin keenam, Novanto meminta pembatalan terhadap seluruh penetapan yang dikeluarkan KPK. Terakhir Poin ketujuh Novanto meminta hakim untuk menghukum termohon (KPK) untuk membayar biaya perkara praperadilan atau apabila Pengadilan Negeri Jakarta Selatan berpendapat lain mohon ptuusan yang seadil-adilnya.

Dari pengajuan pemohonan gugatan praperadilan tersebut dan putusan Hakim Cepi Iskandar yang mengabulkan gugatan dimana cukup menarik perhatian publik bahwa salah satu pertimbangan Hakim dalam putusan yakni alat bukti dan barang bukti yang sama dalam perkara pidana yang berbeda tidak dapat digunakan kembali. ${ }^{33)}$ Alat bukti dan barang bukti

33) Pertimbangan mengenai alat bukti dan barang bukti dalam putusan praperadilan pengadilan negeri jakarta selatan Nomor 97/Pid.Prap/2017/Pn.Jkt.Sel “

Halaman 207-208 "Alat bukti perkara orang lain in casu adalah Perkara No. 41/PID.SUS/TPK/2017/PN.JKT.PST. Secara yuridis alat bukti dalam perkara orang lain tidak boleh dipergunakan untuk membuktikan perkara yang lain lagi. UU KPK mensyaratkan penetapan tersangka berdasarkan adanya minimal 2 (dua) alat bukti yang sah, Termohon tidak membedakan mana yang merupakan barang bukti dan mana yang termasuk alat bukti yang sah berdasarkan ketentuan yang diatur dalam KUHAP, sehingga tindakan Termohon menetapkan Pemohon sebagai Tersangka adalah tidak sah dan tidak berdasar hukum.

Halaman 213 "Bahwa dalam Putusan No. 41/PID.SUS/TPK/2017/PN.JKT.PST. tersebut, nama Pemohon tidak disebut dan tidak masuk dalam pertimbangan Majelis Hakim yang memeriksa perkara tersebut sebagai pihak yang turut serta melakukan tindak pidana, yang disebutkan dalam SPDP tersebut di atas yang dikeluarkan oleh Termohon terhadap diri Pemohon meminjam alat bukti perkara orang lain in casu adalah perkara No. 41/PID.SUS/TPK/2017/PN.JKT.PST., atas nama Terdakwa Irman dan Sugiharto, sehingga cacat 
tersebut mengacu pada 200 (dua ratus) barang bukti yang tertulis sebagai bukti permulaan atau bukti yang cukup dalam menetapan status tersangka seseorang. Dasar hukum mengenai alat bukti sudah tertuang dalam Pasal 184 KUHAP sedangkan untuk barang bukti tertuang dalam Pasal 39 ayat (1) KUHAP. Objek praperadilan yang sudah diperluas yakni salah satunya mengenai penetapasan status tersangka seseorang yakni dalam Pasal 1 angka 14 KUHAP menyatakan bahwa tersangka ${ }^{34)}$ adalah seorang yang karena perbuatannya atau keadaannya berdasarkan bukti permulaan patut diduga sebagai pelaku tindak pidana. Dimana penetapan tersangka ini dilakukan setelah dilakukan penyidikan. ${ }^{35)}$ Makna bukti permulaan ini tidak dijelaskan dalam KUHAP sehingga untuk memberikan kepastian hukum maka Mahkamah Konstitusi menyatakan bahwa "bukti permulaan", "bukti permulaan yang cukup", dan "bukti yang cukup" yang tertuang dalam Pasal 1 angka 14, Pasal 17, dan Pasal 21 ayat (1) KUHAP harus dimaknai sebagai "minimal dua alat bukti" yang termuat dalam Pasal 184 KUHAP. ${ }^{36)}$

Secara teoritis terdapat 4 teori mengenai sistem buktian, dimana HIR maupun KUHAP menganut sistem pembuktian berdasarkan undang-undang secara negative (Negative Wettelijk Bewijs Theorie) yang mengacu pada Pasal 183 KUHAP yang menyatakan Hakim tidak boleh menjatuhkan pidana kepada seorang kecuali apabila dengan sekurang-kurangnya dua alat bukti yang sah ia memperoleh keyakinan bahwa suatu tindak pidana benarbenar terjadi dan bahwa terdakwalah yang bersalah melakukannya. Selain itu, Menurut Wirdjono Prodjodikoro Indonesia menganut sistem pembuktian berdasarkan keyakinan hakim atas alasan yang logis (conviction

\footnotetext{
hukum, karena secara yuridis alat bukti dalam perkara orang lain tidak boleh dipergunakan untuk membuktikan perkara yang lain lagi.

34) Mengacu pada Pasal 17 KUHAP bahwa perintah penangkapan dilakukan terhadap seorang yang diduga keras melakukan tindak pidana berdasarkan bukti permulaan yang cukup

${ }^{35)}$ Pasal 1 angka 2 KUHAP menyatakan penyidikan adalah serangkaian tindakna penyidik dalam hal dan menurut cara yang diatur dalam undang-undang ini untuk mencari serta mengumpulkan bukti yang dengan bukti itu membuat terang tentang tindak pidana yang terjadi dan guna menemukan tersangkanya.

http://www.mahkamahkonstitusi.go.id/index.php?page=web.Berita\&id=10796\#.Wwqo0VOWS1s, diakses pada 27 Mei 2018, pukul 20:43 WIB.
} 
in raisone) dengan mengutamakan keyakinan hakim sebagai dasar alasan menghukum atau memutus terdakwa, didukung dengan pertimbangan yang nyata dan logis serta diterima oleh akal pikiran yang sehat.

Pertimbangan Hakim Cepi Iskandar yang menyatakan bahwa alat bukti yang "Alat bukti perkara orang lain in casu adalah Perkara No. 41/PID.SUS/TPK/2017/PN.JKT.PST. Secara yuridis alat bukti dalam perkara orang lain tidak boleh dipergunakan untuk membuktikan perkara yang lain lagi" telah melalui penafsiran jenis analogische interpretative yakni Cara penafsiran ini adalah apabila terdapat sesuatu yang diatur dengan tegas oleh sesuatu undang-undang dan kemudian terdapat juga lain hal yang tidak diatur dengan tegas oleh undang-undang, sedang hal lain ini mempunyai dasar dan sifat yang sama dengan hal yang telah diatur dengan tegas oleh undang-undang tersebut, maka undang-undang yang telah mengatur sesuatu hal secara tegas itu, dipergunakan untuk menafsirkan hal yang tidak diatur dengan tegas oleh undang-undang. ${ }^{37)}$ Hakim Cepi Iskandar mengacu pada beberapa pengaturan salah satunya menafsirkan Pasal 183 KUHAP terkait alat bukti yang sama tidak boleh dipergunakan untuk perkara lain dan telah melalui keyakinan hakim.

Secara nyata alat bukti yang sama sering digunakan dalam menyelesaikan perkara lain. Kasus korupsi menjadi salah satu contoh penggunaan alat bukti yang sama dalam perkara pidana berbeda karena adanya hubungan antara satu pelaku dengan pelaku lain atau yang di kenal dengan turut serta ataupun pembantuan. Menurut Dr. Dian Andriawan, S.H., M.H. selaku ahli hukum pidana dan dosen hukum pidana Universitas Trisakti menyatakan bahwa jika alat bukti yang sama dalam beberapa perkara tidak dapat digunakan untuk menyelesaikan perkara yang berkaitan maka bisa dipakai kembali apabila perbuatan yang dilakukan, itu dilakukan lebih dari satu orang jadi berupa tindakan bersama-sama. Selain itu, pengaturan mengenai alat bukti yang sama dalam perlkara pidana yang

${ }^{37)}$ P.A.F. Lamintang, S.H. dan C. Djisman Samosir, S.H., Delik-delik Khusus Kejahatan yang ditujukan terhadap hak milik dan lain-lain hak yang timbul dari hak milik, (Bandung: TARSITO Bandung, 2010), hal. 3-11. 
berbeda itu tidak ada pengaturan secara eksplisit sehingga melalui penafsiran hakim yakni hakim mempunyai independensi untuk melakukan penafsiran. Namun, perlu di cermati secara nyata bahwa penggunaan alat bukti yang sama sudah sering terjadi dalam menyelesaikan perkara pidana.

Dr. Metty Hadiati, S.H., M.H. selaku ahli pidana dan dosen hukum pidana di Universitas Trisaksi menyampaikan pendapatnya terkait putusan praperadilan no. 97/pid.prap/2017/pn.jkt.sel ini bahwa atas pertimbanagn Hakim Cepi Iskandar akan ada kemungkinan menjadi yurisprudensi baru. Jika dibuat yurisprudensi baru, maka dalam menyelesaikan perkara pidana dengan penyertaan seperti korupsi dimana keterangan tersangka nantinya tidak dapat dijadikan pengembangan penyidikan berikutnya bagi tersangka yang lain. Itu akan menjadi konsekuensi.

Sehingga dalam menjatuhkan putusan hakim yang mempunyai independensi dalam memutus dan dapat melakukan penafsiran terhadap peraturan yang ada dan juga sejalan dengan sistem pembuktian yang dianut di Indonesia yakni sistem pembuktian berdasarkan undang-undang yang negatif atau minimal 2 (dua) alat bukti dan keyakinan hakim serta sistem pembuktian keyakinan hakim yang harus didasari alasan dan pertimbangan yang jelas karena nantinya dapat menjadi acuan untuk penyelesaian perkara pidana selanjutnya.

\section{PENUTUP}

\section{A. Kesimpulan}

1. Pengaturan mengenai alat bukti dan barang bukti dalam perkara pidana di Indonesia diatur dalam Pasal 184 Kitab Undang-Undang Hukum Acara Pidana yang di dalamnya menyebutkan bahwa alat bukti yang sah adalah: keterangan saksi, keterangan ahli, surat, petunjuk dan keterangan terdakwa. Dalam sistem pembuktian hukum acara pidana yang menganut stelsel negatief wettelijk, hanya alat-alat bukti yang sah menurut undang-undang yang dapat dipergunakan untuk pembuktian. Selanjutnya mengenai barang bukti dalam perkara 
pidana di Indonesia meskipun tidak diatur secara eksplisit mengenai apa itu barang bukti, namun Kitab Undang-Undang Hukum Acara Pidana Indonesia memberikan petunjuk mengenai barang bukti itu sendiri yang dimuat dalam Pasal 39 ayat (1) mengenai apa-apa saja yang dapat disita sehingga barang-barang yang disebutkan dalam pasal tersebut dapat diartikan sebagai barang bukti dalam perkara pidana.

2. Pertimbangan Hakim Cepi Iskandar dalam putusan praperadilan Pengadilan Negeri Jakarta Selatan Nomor 97/Pid.prap/2017/Pn.Jkt.Sel yang menyatakan bahwa secara yuridis alat bukti dalam perkara orang lain tidak boleh dipergunakan untuk membuktikan perkara yang lain lagi. Senyatanya pengaturan mengenai penggunaan alat bukti yang sama dalam suatu perkara tidak secara tegas diatur dalam peraturan perundang-undangan yang ada di Indonesia memberikan kewenangan hakim untuk menggunakan independensi hakim dalam melakukan penafsiran terhadap suatu peraturan perundang-undangan yang ada guna memberikan suatu jawaban yang dapat digunakannya dalam membuat keputusan sesuai dengan keyakinan hakim. Namun pada kenyataannya penafsiran Hakim Cepi Iskandar dalam kasus ini memunculkan berbagai pendapat dari para ahli hukum pidana karena dirasa kurang tepat mengingat dalam kenyataannya, penggunaan alat bukti yang sama banyak digunakan dalam menyelesaikan perkara pidana, terlebih dalam kasus korupsi yang menjerat setya novanto sendiri merupakan suatu kesatuan kasus "korupsi e-ktp" yang menjerat banyak pelaku sehingga masih memiliki benang merah dan saling berhubungan sehingga alat bukti yang digunakan pun secara langsung akan memiliki keterkaitan satu sama lain. Putusan praperadilan tersebut jika tidak diperbaiki atau diuji kembali maka ditakutkan akan menjadi yurisprudensi yang justru akan mempersulit penyelesaian perkara pidana dengan jenis penyertaan atau yang berhubungan antara satu pelaku dengan beberapa pelaku. 


\section{B. Saran}

1. Perlu dibentuknya suatu peraturan yang mengatur tentang penggunaan alat bukti yang sama terhadap suatu perkara pidana dikarenakan dalam kenyataannya banyak terjadi penggunaan alat bukti yang sama dalam beberapa perkara pidana sedangkan dasar hokum yang mengatur menganai hal tersebut tidak ada sehingga hakim harus melakukan interpretasi dan penafsiran sendiri yang menyebabkan timbul kekhawatiran mengenai adanya multitafsir yang dapat menimbulkan tidak adanya kepastian hokum bagi masyarakat.

2. Bagi para penegak hukum hendaknya menggunakan kewenangannya dengan sebijak mungkin terutama hakim yang memiliki hak independensi dalam memutus perkara dengan melakukan penafsiran atau interpretasi terhadap suatu hal yang tidak diatur secara eksplisit di dalam peraturan perundang-undangan. Perlunya sikap bijak tersebut dikarenakan putusan hakim yang telah dijatuhkan dikemudian hari dapat dijadikan sebagai yurisprudensi dengan artian bahwa hakim selanjutnya dengan perkara yang hampir sama dapat sewaktu-waktu menggunakan putusan hakim sebelumnya sebagai dasar hukum dalam memutus perkara yang sedang ia tangani, sehingga dikhawatirkan dapat menyebabkan sistem pemidanaan yang ada menjadi berubah.

\section{DAFTAR PUSTAKA}

\section{A. Buku}

Afiah, Ratna Nurul. Barang Bukti Dalam Proses Pidana. (Jakarta: Sinar Grafika, 1989).

Alfitra, Hukum Pembuktian dalam Beracara Pidana, Perdata dan Korupsi di Indonesia, (Jakarta: Raih Asa Sukses, 2011).

Ali, H. Zainudin. Metode Penelitian Hukum, (Jakarta: Sinar Grafika, 2009).

Diantha, I Made Pasek. Metodologi Penelitian Hukum Normatif dalam Justifikasi Teori Hukum, Cet ke-1, (Jakarta: Prenada Media Group,2016). Hamzah, Andi. Asas-Asas Hukum Pidana. Cetakan Ke-4. (Jakarta: PT Rienka Cipta, 2010). 
Harahap, M. Yahya. Pembahasan Permasalahan dan Penerapan KUHAP, Pemeriksaan Sidang Pengadilan, Banding, Kasasi dan Peninjauan Kembali. Edisi Kedua. (Jakarta: Sinar Grafika, 2006).

Hasibuan, Ansori, Syarifuddin Petenasse, dan Ruben Ahmad. Hukum Acara Pidana, (Bandung: Angkasa, 1990).

Hiariej, O.S Eddy. Teori \& Hukum Pembuktian. (Jakarta: Erlangga, 2012).

Ibrahim, Johny. Teori dan Metodologi Penelitian Hukum Normatif, (Malang: Publishing, 2006).

Lamintang, P.A.F, S.H. dan C. Djisman Samosir, S.H. Delik-delik Khusus Kejahatan yang ditujukan terhadap hak milik dan lain-lain hak yang timbul dari hak milik. (Bandung: TARSITO Bandung, 2010).

Marzuki, Peter Mahmud. Penelitian Hukum, (Edisi Revisi). (Jakarta: Kencana Prenada Media Group, 2009).

Prodjohamidjojo, Martiman. Sistem Pembuktian dan Alat-alat Bukti, (Jakarta: Ghalia Indonesia, 1983).

Sasangka, Hari dan Lily Rosita. Hukum Pembuktian Dalam Perkara Pidana. (Bandung: Mandar Maju, 2003).

Soeroso, R. Pengantar Ilmu Hukum. Cetakan Ke-11. (Jakarta: Sinar Grafika, 2009).

B. Peraturan Perundangan

HIR (Het Herziene Indonesisch Reglement), (Reglement Indonesia Baru). Statblad Tahun 1941 No. 44

Indonesia. Undang-Undang Dasar Negara Republik Indonesia Tahun 1945. Kitab Undang-Undang Hukum Pidana.

Peraturan Kepala Kepolisian Negara Republik Indonesia Nomor 14 Tahun 2012 tentang Manajemen Penyidikan Tindak Pidana.

\section{Putusan Pengadilan;}

Indonesia. Putusan Praperadilan Pengadilan Negeri Jakarta Selatan Nomor: 97/Pid.Prap/2017/Pn.Jkt.Sel, 29 September 2017.

. Putusan Mahkamah Konstitusi Republik Indonesia Nomor: 20/PUU-XIV/2016, 7 September 2016.

. Putusan Mahkamah Konstitusi Republik Indonesia Nomor: 42/PUU-XV/2017, 10 Oktober 2017.

D. Artikel Internet

Anonim. "Simak! Ini 7 Poin Permohonan Praperadilan Setya Novanto". https://www.indopos.co.id/index.php/read/2017/09/20/110884/simak-ini7-poin-permohonan-praperadilan-setya-novanto, diakses 27 Mei 2018 pukul 20:16 WIB.

Chairunnisa, Ninis. "Praperadilan Setya Novanto, MA: Tak hilangkan Perbuatan Pidana".https://nasional.tempo.co/read/1021611/praperadilansetya-novanto-ma-tak-hilangkan-perbuatan-pidana, diakses 3 Februari 2018 pukul 15:20 WIB.

Gabrillin, Abba. “KPK Tetapkan Setya Novanto Tersangka Kasus E-KTP”. http://nasional.kompas.com/read/2017/07/17/19034751/kpk-tetapkansetya-novanto-tersangka-kasus-e-ktp, diakses 3 Februari 2018 pukul 15:10 WIB. 
Konstitusi, Mahkamah. "MK: Penetapan Tersangka Masuk Lingkup Praperadilan".http://www.mahkamahkonstitusi.go.id/index.php?page=we b.Berita\&id=10796\#.WxT2z1OWS1t, diakses 27 Mei 2018 pukul 20:43 WIB.

Nadlir, Moh. "ICW Kemukakan 6 Kejanggalan Putusan Hakim Praperadilan Setya

Novanto".http://nasional.kompas.com/read/2017/09/30/06581381/icwkemukakan-6-kejanggalan-putusan-hakim-praperadilan-setya-novanto, diakses 3 Februari 2018 pukul 15:30 WIB.

\section{E. Wawancara}

Andriawan, Dian. Wawancara dengan penulis, Ahli Hukum Pidana serta Dosen Hukum Pidana Universitas Trisaksi, Gedung Fakultas Hukum Universitas Trisakti Lantai 3, Jakarta 4 Mei 2018.

Guntur, Achmad, S.H. Wawancara dengan penulis, Hakim Pengadilan Negeri Jakarta Selatan, Kantor Hakim Pengadilan Negeri Jakarta Selatan Lantai 2, Jakarta 18 Mei 2018.

Rahmawarti, Metty. Wawancara dengan penulis, Ahli Hukum Pidana serta

Dosen Hukum Pidana Universitas Trisaksi, Gedung Fakultas Hukum Universitas Trisakti Lantai 3, Jakarta 2 Mei 2018. 